Asian J Agric \& Biol. 2021(2). $\mathrm{AJAB}$ DOI: $10.35495 / a j a b .2019 .12 .562$

Original Article

\title{
GC-MS analysis and antimicrobial activity of the aqueous extract from the bulbs of Allium chinense G. Don. cultivated in North Sumatra, Indonesia
}

\author{
Frans Grovy Naibaho ${ }^{1}$, Adrian Hartanto ${ }^{2}$, Maria Bintang ${ }^{3}$, It Jamilah ${ }^{2}$, Nunuk Priyani², Ebrry Dwi Putra ${ }^{1}$ \\ ${ }^{1}$ Department of Biology, Faculty of Mathematics and Natural Sciences, Universitas Palangka Raya, Palangka Raya 73111, \\ Indonesia \\ ${ }^{2}$ Department of Biology, Faculty of Mathematics and Natural Sciences, Universitas Sumatera Utara, Medan 20155, Indonesia \\ ${ }^{3}$ Department of Biochemistry, Faculty of Mathematics and Natural Sciences, IPB University, Bogor 16880, Indonesia
}

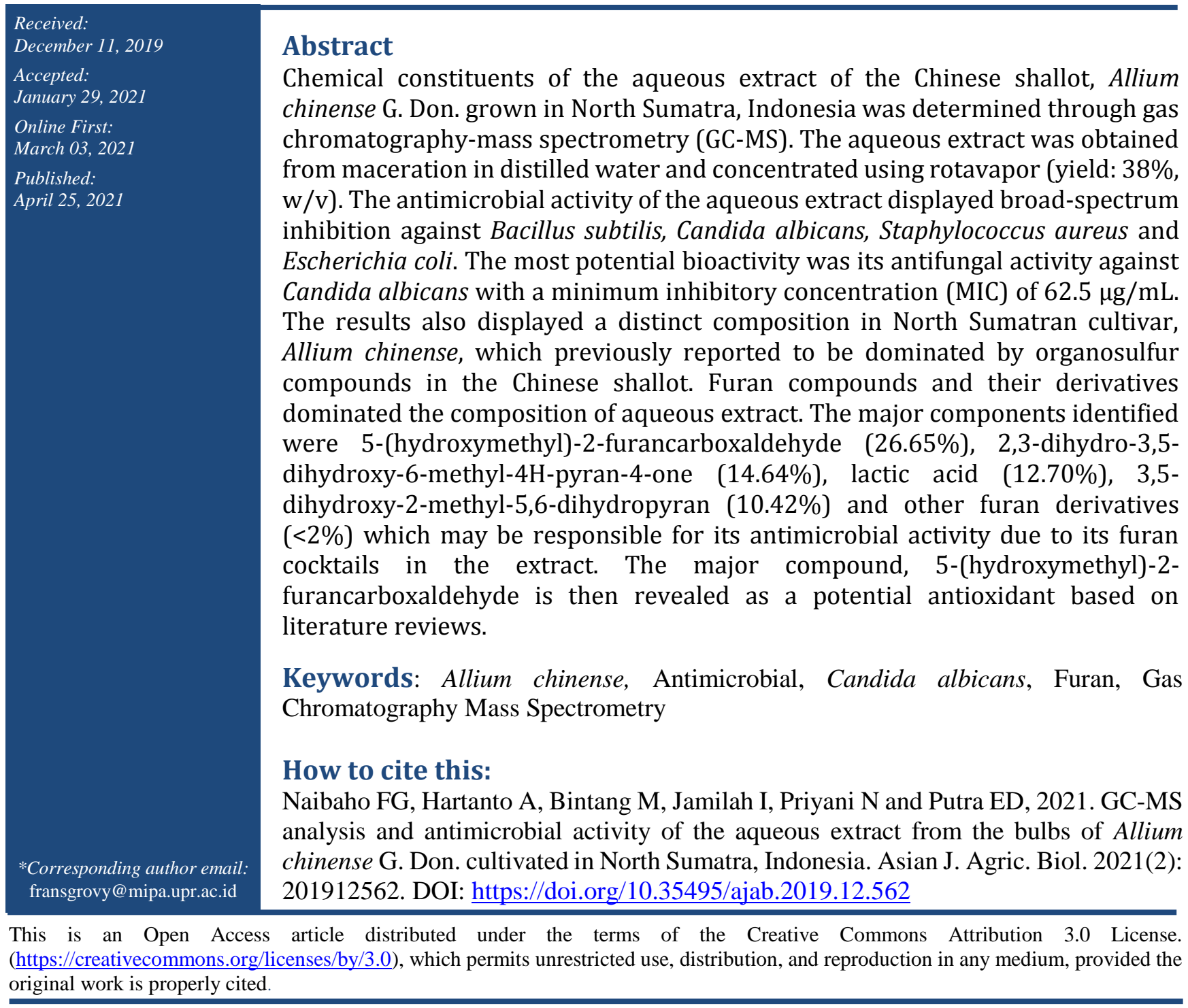




\section{Introduction}

Allium spp. is a tropical plant species commonly used as spices, food preservatives, and medicinal ingredients (Keusgen et al., 2006; Sharma, 2004; Satyal et al., 2017). Its bioactive compounds have been intensively evaluated, explaining its oldest and global cultivation for many centuries (Benkeblia and Lanzotti, 2007). There are about $>280$ species of Allium with the most notable species, such as Allium sativum, A. cepa, A. tuberosum, A. ascalonicum, A. minutiflorum, A. schoenoprasum, etc (Rabinowitch and Currah, 2002).

A phytochemical study from their bioactive extracts showed a composition of essential oil and organosulfur compounds such as allicin, alliin, di-allyl tri-sulfide, ajone, di-allyl di-sulfide, methyl methanethiosulfinate, which may contribute to their health and medical properties (Putnik et al., 2019). Reports regarding the potential bioactivities of Allium extract grew the attention of researchers as they have been described as anti-inflammation, antioxidative, antihistamine, insecticidal, anticancer, antibacterial, and antifungal agents (Bah et al., 2012; Bakht et al., 2011; Safari et al., 2014; Meriga et al., 2012; Najjaa et al., 2009).

Bioactive compounds of Allium expressing antibacterial activity is the most common preliminary study in recognizing their valuabilities. The source of the antibacterial compounds may be obtained by extraction from bulbs, flowers, leaves, and roots. Antibacterial activity from Allium species showed a broad spectrum inhibition against bacterial pathogens, such as Vibrio cholerae, Staphylococcus aureus, Escherichia coli, Streptococcus mutans, Pseudomonas aeruginosa, and Candida albicans (Bakht et al., 2013; Bakht et al., 2014; Deresse, 2010; Fani et al., 2007; Hannan et al., 2010; Lemar et al., 2005).

The traditional use of Allium species has been documented in some ethnobotanical studies in Indonesia. The tuber or bulbs of Allium cepa L. mixed with water were used as a cleaning solution to treat cataract in the local community of Ranggawulung, East Java, Indonesia (Putri et al., 2016). The consumption of raw $A$. sativum bulbs by local community of Turgo, Yogyakarta, Indonesia was perceived as a herbal medicine in lowering high blood pressure and cholesterol levels (Nahdi et al., 2016). The Batak Karo tribe in North Sumatra, Indonesia purposively grew many medicinal plants in their home garden, for example A. tuberosum or Gundara belang for daily consumption as herbal medicine ingredients (Silalahi and Nisyawati, 2018). In a more recent study, both $A$. cepa and $A$. sativum bulbs were reported to be practically used as oral and topical medicine to treat various ailments, e.g fever, high blood pressure, injury, and abdominal pain by the Batak Toba tribe in North Sumatra, Indonesia (Silalahi et al., 2019).

Bawang Batak is one of local Allium species, cultivated in North Sumatra, Indonesia and identified as Allium chinense G. Don, originating from Chinese region. In North Sumatra, the shallot is primarily used as food ingredient or eaten raw in traditional cuisine namely arsik ikan mas. Meanwhile, no health properties have been reported so far. A laboratory investigation reported that $A$. chinense organic extracts ( $\mathrm{MeOH}$, EtOAc, hexane) displayed notable antifungal and antimicrobial activities against human clinical pathogens (Naibaho et al., 2015).

Regarding its future application, the present study investigated the antimicrobial activity of aqueous extract of $A$. chinense bulbs obtained through the decoction technique as one of many traditional processing of herbal ingredients. Besides, differences in chemical composition are suspected between the Chinese and North Sumatran A. chinense which may imply the impacts of geographical and cultivation conditions on the phytochemical investment among intraspecific organisms.

\section{Material and Methods}

\section{Plant material}

Allium chinense G. Don. or bawang batak (Ind.) was purchased from local farmer in Sidikalang district, Dairi regency, North Sumatra, Indonesia. The duplicate specimen was authenticated in Herbarium Bogoriense, Indonesian Institute of Sciences, Cibinong, Indonesia for species identification and confirmation.

\section{Preparation of aqueous extract}

Fresh Allium chinense bulbs were sliced to a thickness of $\pm 5 \mathrm{~mm}$ then the decoction technique was adopted to yield the aqueous extract (Ennaifer et al., 2018). Approximately $25 \mathrm{~g}$ of simplicia in $250 \mathrm{~mL}$ distilled water $(1: 10$, w/v $)$ was boiled in $500 \mathrm{~mL}$ flask at $100^{\circ} \mathrm{C}$ for 15-20 min or until the water volume was halved. Filtrate was concentrated using rotavapor in vacuo at temperature below $60^{\circ} \mathrm{C}$ to yield crude aqueous extract of $A$. chinense. Decoction process may be repeated in 
an additional batch until adequate volume of aqueous extract is obtained. The crude extract was stored in refrigerator $\left(4^{\circ} \mathrm{C}\right)$ prior experimentation.

\section{Preliminary phytochemical screening}

The aqueous extract was qualitatively screened for the presence of phytochemical constituents, i.e., alkaloids, flavonoids, organosulfur, saponins, steroids, tannins, and terpenoids based on color-forming reactions (Harborne, 1996).

\section{Antimicrobial activity assay}

The crude aqueous extract was tested for its antimicrobial activity using the agar well diffusion method (Balouiri et al., 2016). In this study, clinical pathogens were Bacillus subtilis, Escherichia coli, Salmonella typhii, Staphylococcus aureus, and Candida albicans retrieved from Laboratory of Bacteriology, Faculty of Veterinary Medicine, Bogor Institute of Agricultural Sciences, Bogor, Indonesia. Bacterial inoculum was initially grown in tryptone soya agar (TSA) (Oxoid ${ }^{\mathrm{TM}}$, UK) while $C$. albicans was grown in potato dextrose agar (PDA) (Difco ${ }^{\mathrm{TM}}$, USA) at $37^{\circ} \mathrm{C}$ for $24 \mathrm{hr}$. Bacteria and yeast colonies were picked up using sterile cotton swab and dipped into $0.85 \%$ physiological saline $(\mathrm{NaCl})$ solution to obtain $\mathrm{OD}_{600}=0.08-0.10 \approx 1.5-2 \times 10^{8} \mathrm{CFU} / \mathrm{mL}$ for bacteria or $1-5 \times 10^{6} \mathrm{CFU} / \mathrm{mL}$ for $C$. albicans. An aliquot of 0.1 $\mathrm{mL}$ microbial suspensions were mixed with $20 \mathrm{~mL}$ of molten $\left(45^{\circ} \mathrm{C}\right)$ Mueller-Hinton agar (MHA) and inoculated into sterile plates upon solidification. Five wells were made by punching a hole using a cork borer with a diameter of $6 \mathrm{~mm}$. The crude aqueous extract was prepared in a $10 \%$ dimethyl sulfoxide (DMSO, $\mathrm{v} / \mathrm{v}$ ) at a concentration of $1000 \mu \mathrm{g} / \mathrm{mL} .50 \mu \mathrm{L}$ of each solution was pipetted into well. Chloramphenicol and Nystatin $(60 \mu \mathrm{g} / \mathrm{mL})$ were used as standard antibiotics or positive controls. $10 \%$ DMSO was used as negative control. Plates were incubated at $37^{\circ} \mathrm{C}$ for $24 \mathrm{hr}$. Clear zones around wells were measured using digital caliper (mm). All experiments were performed in three replicates.

\section{Determination of minimum inhibitory concentration (MIC)}

The MIC value was obtained by testing different concentration of aqueous extract of $A$. chinense by 2fold dilution in $10 \%$ DMSO $(\mathrm{v} / \mathrm{v})$, yielding concentration at $500-1.95 \mu \mathrm{g} / \mathrm{mL}$. The procedure in testing MIC was similar to that previously mentioned in antimicrobial activity assay. Plates were incubated at $37^{\circ} \mathrm{C}$ for $24 \mathrm{hr}$. Clear zones around wells were measured using digital caliper $(\mathrm{mm})$. All experiments were performed in three replicates.

\section{GC-MS (Gas Chromatography-Mass} Spectrometry) analysis

The phytochemical constituents of aqueous extract of A. chinense G. Don. were analyzed with GC-MS equipment (Shimadzu type GCMS-QP2010, Japan). Experimental conditions of GC-MS system were as follows: Rtx-5MS (fused silica) capillary column, flow rate of mobile phase (carrier gas: $\mathrm{He}$ ) was set at $1.50 \mathrm{~mL} / \mathrm{min}$, column oven temperature was set to rise from $50^{\circ} \mathrm{C}$ to $250^{\circ} \mathrm{C}$ at $5^{\circ} \mathrm{C} / \mathrm{min}$ with velocity of 45.1 $\mathrm{cm} / \mathrm{sec}$ and injection volume was $1 \mu \mathrm{L}$. The analysis was run at a range of $40-600 \mathrm{~m} / \mathrm{z}$ and the results were compared based on database in Wiley Spectral library (WILEY7.LIB). A representative of major compounds was re-drawn in chemical structure using ChemDraw online tool.

\section{Results and Discussion}

\section{Phytochemical screening of aqueous extract of Allium chinense}

The existence of antibiotic-resistant pathogens has increased in the last decades, which demands a development and discovery of new drugs, especially those derived from natural products (Cowan, 1999). The main focus of discovering new antibiotics is by exploitation and exploration of various medicinal plant species followed by laboratory testing of their efficacies. (Newman and Cragg, 2012). Based on the qualitative screening results of phytochemicals, $A$. chinense may be considered as a prominent source of antimicrobial agents. The results showed that $A$. chinense aqueous extract contained organosulfurs, saponins, steroids, and triterpenoids although no presence of alkaloids, flavonoids, and tannins were detected in the extract (Table 1).

The presence of organosulfurs, saponins, steroids, and triterpenoids in A. chinense have been documented in previous studies. However, most studies reported the bioavailability of phytochemicals occurring in organic extracts and essential oils from $A$. chinense cultivated in the Chinese region. 
Table-1. Phytochemical screening of aqueous extract of Allium chinense G. Don.

\begin{tabular}{|c|c|c|}
\hline $\begin{array}{l}\text { Phytochemical } \\
\text { constituents }\end{array}$ & Test/Reagents & Result \\
\hline \multirow{3}{*}{ Alkaloids } & Dragendorf test & - \\
\hline & Mayer test & - \\
\hline & Wagner test & - \\
\hline Flavonoid & Shinoda test & - \\
\hline Organosulfur & Silver Nitrate test & + \\
\hline Saponin & \begin{tabular}{|l|l} 
Foam test \\
\end{tabular} & + \\
\hline Steroid & Liebermann-Burchardt test & + \\
\hline Tannin & Braemer test & - \\
\hline Triterpenoid & Liebermann-Burchardt test & + \\
\hline
\end{tabular}

Also, the steroidal saponins and sapogenins are among the well-studied phytochemicals in A. chinense and gaining recent focuses (Sobolewska et al., 2016). The steroidal saponins from $\mathrm{MeOH}$ fraction of $A$. chinense, was reported to inhibit the cellular activities of cyclic AMP phosphodiesterase and $\mathrm{Na}^{+} \mathrm{K}^{+}$ATPase (Kuroda et al., 1995). The isoliquiritigenin and laxogenin, derived from saponins of $A$. chinense showed a significant anti-tumor promoting activity to HeLa cells (Baba et al., 2000). Moreover, three saponins isolated from $A$. chinense showed a protective effect to the stress-induced cardiac damage in the cultured rat cells (Ren et al., 2010). The essential oil or triterpenoids of A. chinense which contained majority of organosulfurs (allyl sulfides) was also as an insecticide, being effective against booklice in the field of post-harvest preservation (Liu et al., 2014). On the contrary, the hyperlipidemic properties of fresh $A$. chinense bulbs were attributed to its flavonoid contents, undetected in the present result (Lin et al., 2016). By considering the bioactivities reported from previous laboratory studies, it may seem promising to evaluate the native $A$. chinense from North Sumatra especially as herbal medicine or pesticide ingredients in the future.

\section{Antimicrobial test}

Antimicrobial activity of $A$. chinense aqueous extract was found to be most effective against Gram positive bacteria and yeast (Table 2). The largest inhibition zone $(\mathrm{mm})$ was observed against Candida albicans reaching $>16 \mathrm{~mm}$ (Figure 1). Minor antibacterial activities were observed from the test against Gram negative bacteria, E. coli and S. typhii, indicating their insensitivity to the aqueous extract.
Table-2. Inhibition zones (mm) of aqueous extract of Allium chinense G. Don.

\begin{tabular}{|c|c|c|c|c|c|}
\hline \multirow{2}{*}{ Sample } & \multicolumn{5}{|c|}{ Microorganism $^{a}$} \\
\cline { 2 - 6 } & $\begin{array}{c}\text { B. } \\
\text { subtilis }\end{array}$ & $\begin{array}{c}\text { E. } \\
\text { coli }\end{array}$ & $\begin{array}{c}\text { S. } \\
\text { aureus }\end{array}$ & $\begin{array}{c}\text { S. } \\
\text { typhii }\end{array}$ & $\begin{array}{c}\text { C. } \\
\text { albicans }\end{array}$ \\
\hline Aqueous extract & $\begin{array}{c}10.31 \pm \\
0.58\end{array}$ & $+/-$ & $\begin{array}{c}10.41 \pm \\
0.53\end{array}$ & $+/-$ & $\begin{array}{c}16.38 \pm \\
0.32\end{array}$ \\
\hline Chloramphenicol & $11 \pm 0.0$ & $\begin{array}{c}18 \pm \\
0.0\end{array}$ & $13 \pm 0.0$ & $\begin{array}{c}12 \pm \\
0.0\end{array}$ & - \\
\hline Nystatin & - & - & - & - & $15 \pm 0.0$ \\
\hline DMSO 10\% (v/v) & - & - & - & - & - \\
\hline
\end{tabular}

- , No inhibition; + / - , slight inhibition $(<7 \mathrm{~mm})$.

${ }^{a}$ Inhibition zones are presented as means (three replicates) $\pm \mathrm{SE}$.

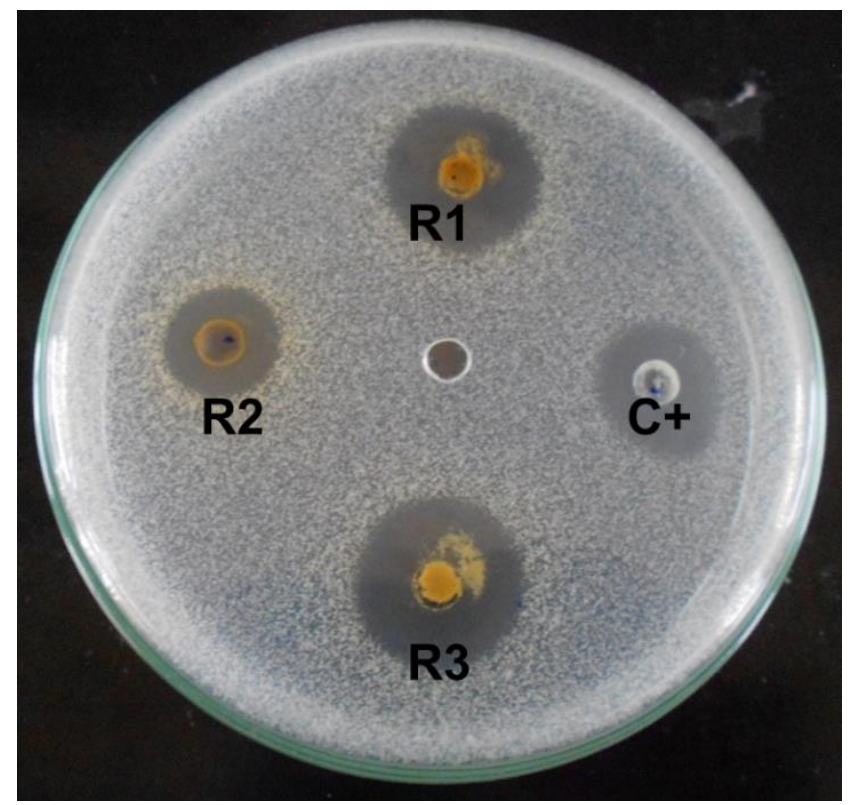

Figure-1. Inhibition zone of aqueous extract of Allium chinense G. Don. $(1000 \mu \mathrm{g} / \mathrm{mL})$ against Candida albicans. R: Replicate 1,2,3; C+: Nystatin $(60 \mu \mathrm{g} / \mathrm{mL})$

On the contrary, Bakht et al. (2011) reported that water extracts showed antibacterial activities against tested Gram negative bacteria e.g Escherichia coli, Salmonella typhii, Klebsiella pneumoniae, and Erwinia carotovora. In general, plant materials extracted with organic solvents may display a more significant antibacterial activities than using only water as solvent (Koohsari et al., 2015). The first investigation using macerated $A$. chinense simplicia in ethyl acetate extract showed a more potent result against bacteria (Naibaho et al., 2015). However, the use of decoction technique in metabolite extraction, showed an increase in anti-Candida albicans activity in this study (previously $<15 \mathrm{~mm}$ ). A similar result 
was also reported in which fresh garlic extract exhibited a stronger anti-Candida than simpliciabased extracts (Lemar et al., 2002). Hence, the bioactivity of Allium species may vary regarding the extraction and processing methods (Farag et al., 2017). The decoction technique is considered the oldest and simplest preparation method of herbal medicines, yet the effectiveness is still under evaluation in different plant species or formulation (Yang et al., 2015). Besides, the decoction technique is the best practice or preferably used by the local community in preparing herbal medicine for daily uses and treatments of ailments. Since the best results was observed against C. albicans, a further test of MIC determination was performed, revealing the value of $>62.5 \mu \mathrm{g} / \mathrm{mL}$ (Figure 2). By determining the MIC of plant extracts, we may use the extract in a more effective concentration while exhibiting the best bioactivity.

The more sensitivity of Gram positive than gramnegative bacteria to herbal extracts has also been documented in past investigations. An antibacterial study of 25 Australian herbs revealed that Bacillus cereus and B. subtilis were more susceptible to the herbal extracts than Pseudomonas aeruginosa and Aeromonas hydrophila based on the disk diffusion method (Cock, 2008).The antibacterial test of different herbal extracts native to India and Nepal against human pathogenic bacteria revealed that the most sensitive bacteria were $B$. subtilis and $S$. aureus. In contrast, most Gram negative bacteria produced an insignificant inhibition based on agar well diffusion method (Joshi et al., 2009).

Gram positive bacteria are more sensitive than Gram negative bacteria because of the differences in the cell wall composition and membrane permeability. In Gram negative bacteria, the cell envelope and composition is more complex than in Gram positive bacteria. With its impermeable feature, the lipopolysaccharide layer may hinder the input of bioactive metabolites into the interior of cells yet reducing the effectivity of antibiotics (Hodges, 2002). The antibacterial activity by herbal extracts, must be initiated through a hydrophilic-lipophilic balance between soluble drugs and cell environment (Kanazawa et al., 1995). The herbal drugs or extracts must be soluble in the aqueous environment to make a contact with the target bacteria. The contact of a more lipophilic extract will initiate the interaction with the cell wall of Gram negative bacteria, leading to various solubilization, leakage, disruption or even direct passage into cell interior (Branen and Davidson,
2005). Moreover, the aqueous extract of $A$. chinense was subjected to GC-MS analysis to provide hints on the composition of bioactive phytochemicals, explaining the general mechanism of antimicrobial activity.

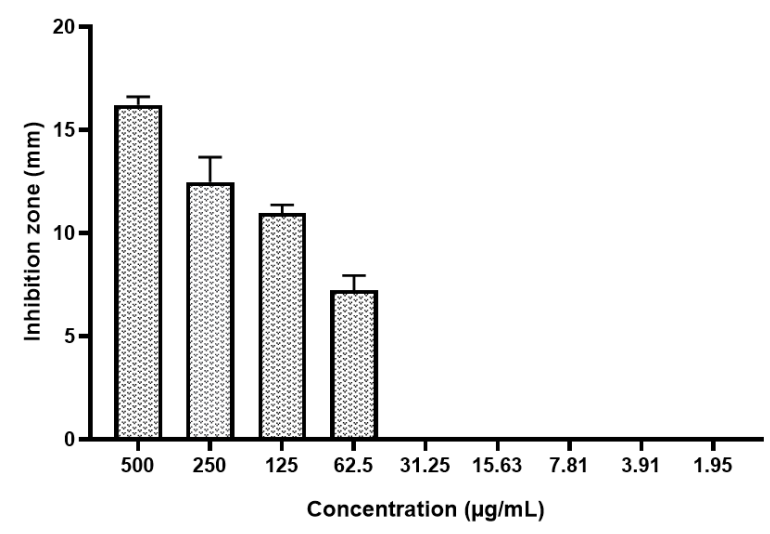

Figure-2. Minimum inhibitory concentration $(\mu \mathrm{g} / \mathrm{mL})$ of aqueous extract of Allium chinense $\mathbf{G}$. Don. Data are presented as means of three replicates.

\section{Phytochemical constituents of $A$. chinense aqueous extract by GC-MS analysis}

The composition of the aqueous extract of Allium chinense G. Don. Bulbs grown in North Sumatra was determined by GC-MS as shown in Table 3. In this study, we identified the major components based on spectral database in library. The highest portion of phytochemicals in the extract was found to be 5(hydroxymethyl)-2-furancarboxaldehyde (26.65\%), followed with 2,3-dihydro-3,5-dihydroxy-6-methyl4H-pyran-4-one (14.64\%), L-(+)-lactic acid (12.70\%), 3,5-Dihydroxy-2-methyl-5,6-dihydropyran (10.42\%) (Figure 3).

The presence of 2,3-dihydro-3,5-dihydroxy-6-methyl4H-pyran-4-one was detected again during a retention time of 9.515, suggesting an unequal distribution of sample or unidentified derivatives based on the library database. In general, the significant compounds detected were furan, furfural and its derivatives in the aqueous extract. The rest of the extract contained either minor components of alcohol compounds or organic acids. It can be seen that no aromatic terpenoids or volatile compounds detected in the bulbs, while the volatile oils along with organosulfurs were reported previously as the most dominant phytochemicals in $A$. chinense (Bah et al., 2012). Prior investigation using GC-MS analysis to identify the chemical composition 
of the EtOAc extract of North Sumatran A. chinense also revealed dominant furan and furfural compounds (Naibaho et al., 2015).

Table-3. Compounds identified in the aqueous extract of Allium chinense G. Don.

\begin{tabular}{|c|c|c|}
\hline RT & Compound & \% Conc. \\
\hline 5.581 & L-(+)-lactic acid & 12.70 \\
\hline
\end{tabular}

\begin{tabular}{|l|l|c|}
\hline 5.667 & 2,3-dihydro-3,5-dihydroxy-6-methyl-4H-pyran-4-one & 14.64 \\
\hline
\end{tabular}

\begin{tabular}{|l|l|l|}
\hline 6.005 & Cyclohexanone & 0.70 \\
\hline 6.273 & $1,2.3,4-$ Diepoxycyclopentane \\
\hline
\end{tabular}

\begin{tabular}{|l|l|l|}
\hline 6.273 & $1,2: 3,4-D i e p o x y c y c l o p e n t a n e$ & 0.60 \\
\hline 6.826 & Butyrolactone & 1.19 \\
\hline
\end{tabular}

\begin{tabular}{|l|l|l|}
\hline 6.993 & 2(5H)-Furanone & 1.70 \\
\hline
\end{tabular}

\begin{tabular}{|l|l|c|}
\hline 7.442 & 2-Methylpentane & 0.37 \\
\hline 7.895 & Hyacinthin & 1.24
\end{tabular}

\begin{tabular}{|l|l|l|}
\hline 8.583 & Piperidine & 1.24 \\
\hline 8.941 & $2.5-$ Dimethyl-4-hydroxy-3(2H)-furang \\
\hline
\end{tabular}

\begin{tabular}{|l|l|l|}
\hline 8.941 & 2,5-Dimethyl-4-hydroxy-3(2H)-furanone & 2.55 \\
\hline 9.515 & 2,3-Dihydro-5-hydroxy-6-methyl-4H-pyran-4-one & 2.82
\end{tabular}

\begin{tabular}{|c|l|c|}
\hline 9.515 & 2,3-Dihydro-5-hydroxy-6-methyl-4H-pyran-4-one & 2.8 \\
\hline 10.416 & 2-Acetoxy-5-methylpyrazine & 0.4 \\
\hline
\end{tabular}

\begin{tabular}{|l|l|c|}
\hline 11.191 & 3,5-Dihydroxy-2-methyl-5,6-dihydropyran & 10.42 \\
\hline 12.607 & Levilic acid & 1.96
\end{tabular}

\begin{tabular}{|c|c|}
\hline $12.60^{\circ}$ & Levulinic acid \\
\hline
\end{tabular}

\begin{tabular}{|l|l|c|}
\hline 13.342 & 2H-Pyran-2-one, tetrahydro-4,6-dimethyl- & 0.35 \\
\hline
\end{tabular}

\begin{tabular}{|l|l|c}
13.874 & Isosorbid & 1.1
\end{tabular}

\begin{tabular}{|l|l|l}
\hline 14.122 & 3-Methyl-furan-2-carboxylic acid & 1.89 \\
\hline
\end{tabular}

\begin{tabular}{|l|l|l|}
\hline 15.443 & 5-(hydroxymethyl)-2-furancarboxaldehyde & 26.65 \\
\hline
\end{tabular}

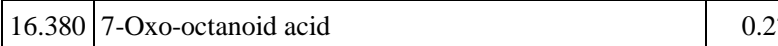

\begin{tabular}{|l|l|l|}
\hline 16.967 & 5-(2-hydroxyethylidene) & 0.21 \\
\hline
\end{tabular}

\begin{tabular}{|l|l|l}
\hline 17.317 & cis-dimethyl morpholine & 0.17 \\
\hline
\end{tabular}

\begin{tabular}{|l|l|l}
\hline 18.246 & n-Heptyl acetate & 0.65 \\
\hline
\end{tabular}

\begin{tabular}{|l|l|l}
\hline 19.024 & Vinyl 2,2-Dimethylpentanoate & 0.46 \\
\hline 19.367 & 6-Undecan & 0.31 \\
\hline
\end{tabular}

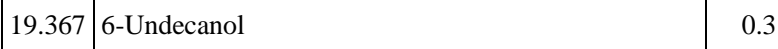

\begin{tabular}{|l|l|c|}
\hline 20.289 & Tri-n-butylborane & 0.8 \\
\hline
\end{tabular}

\begin{tabular}{|l|l|c|}
\hline 21.672 & Tetradecyl alcohol & 0.23 \\
\hline
\end{tabular}

\begin{tabular}{|c|c|}
\hline 22.323 & Ethyl phthalate \\
\hline
\end{tabular}

\begin{tabular}{|l|l|l|}
\hline 24.251 & 1,4-Anhydro-d-mannitol & 4.15 \\
\hline
\end{tabular}

\begin{tabular}{|l|l|l}
\hline 27.247 & 2-Deoxy-D-ribose & 3.69
\end{tabular}

\begin{tabular}{|l|l|l}
\hline 29.530 & Oleic acid & 2.90 \\
\hline
\end{tabular}

\begin{tabular}{|c|l|c|}
\hline 31.617 & D-Mannitol & 0.51 \\
\hline 33.142 & 1-Hexanol, 4-methyl-, acetate & 0.44 \\
\hline 34.717 & 2,2,3,3-Tetramethylcyclopropanemethanol & 0.32 \\
\hline 35.817 & 1-Methyl-trans-2-ethylcyclohexane & 0.26 \\
\hline \multicolumn{2}{|c|}{ Total } & 100.00 \\
\hline
\end{tabular}

RT: Retention time

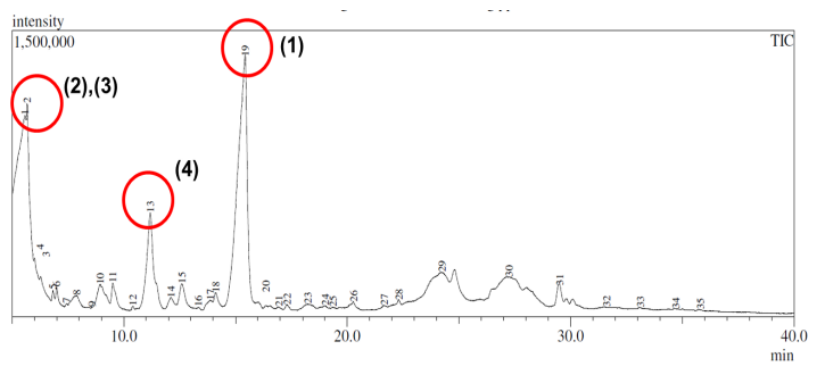

Figure-3. GC-MS chromatogram of aqueous extract of Allium chinense G. Don. The highest detected compounds are: (1) 5-(hydroxymethyl)-2furancarboxaldehyde, (2) 2,3-dihydro-3,5dihydroxy-6-methyl-4H-pyran-4-one, (3) lactic acid, (4) 3,5-dihydroxy-2-methyl-5,6-dihydropyran<smiles>O=Cc1ccc(CO)o1</smiles>

(1)<smiles>CC1=C(O)C(=O)C(O)CO1</smiles>

(2)
Figure-4. Chemical structure of representative furan compounds: (1) 5-(hydroxymethyl)-2furancarboxaldehyde, (2) 2,3-dihydro-3,5dihydroxy-6-methyl-4H-pyran-4-one

However, the concentration of 5-(hydroxymethyl)-2furancarboxaldehyde in aqueous extract was higher than in the previous finding $(18.23 \%)$. Besides, the presence of 5-(hydroxymethyl)-2furancarboxaldehyde was also detected in other Allium species. Some phenols, organosulfurs, and a 5(hydroxymethyl)-2-furancarboxaldehyde compound were present in the aged garlic (A. sativum) extract based on GC-MS and UPLC analysis (Wang et al., 2016). We also pointed out that the detection of 5(hydroxymethyl)-2-furancarboxaldehyde was considered a rare finding within Allium members. Simultaneously, it was also found to be suitable as a strong oxidant along with other phytochemical constituents in A. sativum. Supporting evidence also came from the furfural compound or 5hydroxymethylfurfural (HMF) derived from honey and other food products, which were claimed to possess beneficial health effects to human primarily as antioxidative agents (Shapla et al., 2018). Another reason for the detection of furfural compounds may be 
due to the product of thermal decomposition of sugar (Liu et al., 2018).

Meanwhile, obtaining furfural in standard extraction of Allium, in the case of A. cepa, was achieved during the inactivation of allinase along with decreasing level of volatile organosulfur compounds within increased temperature. Therefore, the heated environment therefore permitted the availability of furfural compounds which may also contribute to the sweetness in the plant material (Crowther et al., 2005). However, it is also noteworthy that both organic and aqueous extract of North Sumatran A. chinense are distinctive compared to the China cultivar through abundant 5-(hydroxymethyl)-2-furancarboxaldehyde and 2,3-dihydro-3,5-dihydroxy-6-methyl-4H-pyran4-one compounds (Figure 4). The differences may be the results of different environmental conditions, playing essential roles in the biosynthesis of secondary metabolites between two cultivars. Environmental conditions such as altitude, climate, light intensity, precipitation, soil nutrients, and temperature of cultivation area as geographical consequences may affect the accumulation of secondary metabolites (Sampaio et al., 2016; Kumar et al., 2017).

The natural composition of dominant furan and furfural compounds in the bulbs may contribute to its future use as natural preservative agents and potential antimicrobial components (Zanatta et al., 2007; Chai et al., 2013). Prior this investigation, the bioactivity of heterocyclic compounds such as furan and furfural, has been reported to exhibit a significant pharmacological activities while possessing antidepressant and anti-inflammatory properties (Burch et al., 1980; Ahmad et al., 2013). Despite its potential as antifungal agent in our study, furan derivatives were notably known as antibacterial agent, especially in the form of synthesized nitrofuran and nitrofurfural compounds (El-Obeid et al., 1985; Lukevits and Demicheva, 1993; Malladi et al., 2017).

Regarding its antifungal properties, other furan derivative such as Dinaphtho[2,1-b]furan-2-ylmethanone also showed inhibitory activities against $C$. albicans with MIC values from 128 to $512 \mu \mathrm{g} / \mathrm{mL}$ (Kirilmis et al., 2009). Further investigation on antifungal activity against $C$. albicans has been reported from 4-(furan-2-yl)-1-(pyridine-4-yl)azetidine-2-one based on disk diffusion method (>30 $\mathrm{mm}$ ) (Sen et al., 2011). Recent investigation reported two furan derivatives namely 5-(undeca-3', $5^{\prime}, 7^{\prime}$-trien$1^{\prime}$-yl)furan-2-ol and 5-(undeca-3',5',7'-trien-1'yl)furan-2-carbonate which displayed significant activities against phytopathogenic fungi, Fusarium oxysporum and Rhizoctonia solani with MIC values from 3.1 to $50 \mu \mathrm{g} / \mathrm{mL}$ (Wu et al., 2017). The prospect of developing antifungal drugs based on these furan constituents may be investigated further in the future, especially those extracted from North Sumatran cultivar containing furan cocktails as potential drugs. The results may also promote its initial use as one of the oral medicine ingredients as shown in its promising anti-Candida activity. This study supported the evidence of decoction technique used in extracting A. chinense for local community as the most straightforward method in preparing herbal medicine in Indonesia.

\section{Conclusion}

The phytochemical composition of aqueous extract of Allium chinense from North Sumatra, Indonesia displayed significant compared to the China cultivar. The aqueous extract obtained from the decoction revealed the presence of organosulfurs, saponins, steroids, and triterpenoids. The extract exhibited potential antibacterial activities against Gram positive bacteria and notable antifungal activity against Candida albicans. The major constituent of the aqueous extract is furan, furfural, and other minor compounds such as alcohols and organic acids. The presence of the abundant 5-(hydroxymethyl)-2furancarboxaldehyde and 2,3-dihydro-3,5-dihydroxy6-methyl-4H-pyran-4-one are considered as the major components responsible for its antimicrobial activity specific to its potent anti-Candida activity with a MIC value of $62.5 \mu \mathrm{g} / \mathrm{mL}$. This is the first report in revealing the distinct phytochemicals in the North Sumatran cultivar of $A$. chinense with possible future utilization prospects.

\section{Acknowledgment}

This research is fully funded by DIPA Universitas Palangka Raya for funding year of 2018, Number: SP.DIPA-042.01.2.400956/2019 on June 20, 2019, with the contract number: 837/UN24.13/PL/2019. The principal and second author also express their gratitudes to Indonesian Ministry of Research and Higher Education (KEMENRISTEK-DIKTI) and Indonesian Ministry of Education and Culture (KEMENDIKBUD) for granting them the BPP-DN and BU scholarship during their study in the universities. 
Disclaimer: None.

Conflict of Interest: None.

Source of Funding: This research is fully funded by DIPA Universitas Palangka Raya for funding year of 2018, No.: SP.DIPA-042.01.2.400956/2019 on June 20, 2019, with the contract No.: 837/UN24.13/PL/2019.

\section{References}

Ahmad A, Ahmad A, Varshney H, Rauf A, Rehan M, Subbarao N and Khan AU, 2013. Designing and synthesis of novel antimicrobial heterocyclic analogs of fatty acids. Eur. J. Med. Chem. 70: 887-900.

Baba M, Ohmura M, Kishi N, Okada Y, Shibata S, Peng J, Yao SS, Nishino H and Okuyama T, 2000. Saponins isolated from Allium chinense G. Don and antitumor-promoting activities of isoliquiritigenin and laxogenin from the same drug. Biol. Pharm. Bull. 23(5): 660-662.

Bah AA, Wang F, Huang Z, Shamsi IH, Zhang Q, Jilani G, Hussain S, Hussain N and Ali E, 2012. Phyto-characteristics, Cultivation and Medicinal Prospects of Chinese Jiaotou (Allium chinense). Int. J. Agric. Biol. 14: 650-657.

Bakht, J, Tayyab M, Ali H, Islam A and Shafi M, 2011. Effect of different solvent extracted sample of Allium sativum (Linn.) on bacteria and fungi. Afr. J. Biotechnol. 10(31): 5910-5915.

Bakht J, Khan S and Shafi M, 2013. Antimicrobial potentials of fresh Allium cepa against positive and gram negative bacteria and fungi. Pak. J. Bot. 45:1-6.

Bakht J, Khan S and Shafi M, 2014. In vitro antimicrobial activity of Allium cepa (dry bulbs) against gram positive and gram negative bacteria and fungi. Pak. J. Pharm. Sci. 27(1): 139-145.

Balouiri M, Sadiki M and Ibnsouda SK, 2016. Methods for in vitro evaluating antimicrobial activity: A review. J. Pharm. Anal. 6(2): 71-79.

Benkeblia N and Lanzotti V, 2007. Allium thiosulfinates: chemistry, biological properties and their potential utilization in food preservation. Food. 1(2): 193-201.

Branen AL and Davidson PM, 2005. Antimicrobial in food. CRC Press, New York, USA.

Burch HA, White RE, Wright GC and Goldenberg MM, 1980. Phenylfurans IV: Spasmolytic 3diethylamino-2,2-(dimethyl) propyl esters of 5- substituted phenyl-2-furancarboxylic acids. J. Pharm. Sci. 69: 107-110.

Chai WM, Liu X, Hu YH, Feng HL, Jia YL, Guo YJ, Zhou HT and Chen QX, 2013. Antityrosine and antimicrobial activities of furfuryl alcohol, furfural and furoic acid. Int. J. Biol. Macromol. 57: 151-155.

Cock IE, 2008. Antibacterial activity of selected Australian native plant extracts. Internet $\mathrm{J}$. Microbiol. 4(2): 1-8.

Cowan MM, 1999. Plant products as antimicrobial agents. Clin. Microbiol. Rev. 12(4): 564-582.

Crowther T, Collin HA, Smith B, Tomsett AB, O'Connor D and Jones MG, 2005. Assessment of the flavour of fresh uncooked onions by tastepanels and analysis of flavour precursors, pyruvate and sugars. J. Sci. Food Agric. 85: 112120.

Deresse D, 2010. Antibacterial effect of Garlic (Allium sativum) on Staphylococcus aureus: An in vitro Study. Asian J. Med. Sci. 2(2): 62-65.

El-Obeid HA, Elnima EI and Al-Badr AA, 1985. Synthesis and antimicrobial activity of new furan derivatives. Pharm. Res. 2: 42-43.

Ennaifer M, Bouzaiene T, Chouaibi M and Hamdi M, 2018. Pelargonium graveolens aqueous decoction: a new water-soluble polysaccharide and antioxidant rich-extract. BioMed Res. Int. 2018: 1-11.

Fani MM, Kohanteb J and Dayaghi M, 2007. Inhibitory activity of Garlic (Allium sativum) extract on multidrug-resistant Streptococcus mutans. J. Indian Soc. Pedod. Prevent. Dent. 25(4): 164-168.

Farag MA, Ali SE, Hodaya RH, El-Seedi HR, Sultani HN, Laub A, Eissa TF, Abou-Zaid FOF and Wessjohann LA, 2017. Phytochemicals studies and antimicrobial activities of Allium cepa Red cv. and A. sativum subjected to different drying methods: A comparative MS-based metabolomics. Molecules. 22(5): 1-18.

Hannan A, Humayun T, Hussain MB, Yasir M and Sikandar S, 2010. In vitro antibacterial activity of Onion (Allium cepa) against clinical isolates of Vibrio cholera. J. Ayub. Med. Coll. Abbottabad. 22(2): 160-163.

Harborne JB, 1996. Phytochemical methods: A guide to modern techniques of plant analysis. Chapman and Hall Inc, London, UK.

Hodges S, 2002. Pharmaceutical applications of microbiological technique in pharmaceutics: The 
science of dosage design. Harcourt Publisher Ltd, London, UK.

Joshi B, Lekhak S and Shorma A, 2009. Antibacterial property of different medicinal plants: Ocimum sanctum, Cinnamomum zeylanicum, Xanthoxylum armatum and Origanum majorana. Kathmandu Univ. J. Sci. Engg. Technol. 5(1): 143-150.

Kanazawa A, Ikeda T and Endo T, 1995. A novel approach to mode of action on cationic biocides: morfological effect on antibacterial activity. J. Appl Bacteriol. 78: 55-60.

Keusgen M, Fritsch RM, Hisoriev H, Kurbonova PA and Khassanov FO, 2006. Wild Allium species (Alliaceae) used in folk medicine and Uzbekistan. J. Ethnobiol. Ethnomed. 2: 1-9.

Kirilmis C, Koca M, Servi S and Gur S, 2009. Synthesis and antimicrobial activity of Dinaphtho[2,1-b]furan-2-yl-methanone and their oxime derivatives. Turk. J. Chem. 33: 375-384.

Koohsari H, Ghaemi EA, Sheshpoli MS, Jahedi M and Zahiri M, 2015. The investigation of antibacterial activity of selected native plants from North of Iran. J. Med. Life. 8(2): 38-42.

Kumar S, Yadav M, Yadav A and Yadav JP, 2017. Impact of spatial and climatic conditions on phytochemical diversity and in vitro antioxidant activity of Indian Aloe vera (L.) Burm. F. S. Afr. J. Bot. 111: 50-59.

Kuroda M, Mimaki Y, Kameyama A, Sashida Y and Nikaido T, 1995. Steroidal saponins from Allium chinense and their inhibitory activities on cyclic AMP phosphodiesterase and $\mathrm{Na}^{+} \mathrm{K}^{+}$ATPase. Phytochemistry. 40(4): 1071-1076.

Lemar KM, Turner MP and Llyod D, 2002. Garlic (Allium sativum) as an anti-Candida agent: A comparison of the efficacy of fresh garlic and freeze-dried extracts. J. Appl. Microbiol. 93: 398405.

Lemar KM, Passa O, Aon MA, Cortassa S, Muller CT, Plummer S, Rourke BO and Lyold D, 2005. Allyl alcohol and Garlic (Allium sativum) extract produce oxidative stress in Candida albicans. Microbiol. 151: 3257- 3265.

Lin YP, Lin YL, Yeh HY, Chuang CH, Tseng SW and Yen YH, 2016. Antihyperlipidemic activity of Allium chinense bulbs. J. Food Drug Anal. 24: 516-526.

Liu M, Su Y and Guo Y, 2018. Determination of highly volatile compounds in fresh onion (Allium cepa L.) by room-temperature enriched headspace-trap coupled to cryotrapping GC-MS. Sep. Sci. Plus. 1: 530-538.

Liu XC, Lu XN, Liu QZ and Liu ZL, 2014. Evaluation of insecticidal activity of the essential oil of Allium chinense G. Don and its major constituents against Liposcelis bostrychophila Badonnel. J. Asia Pac. Entomol. 17: 853-856.

Lukevits E and Demicheva L, 1993. Biological activity of furan derivatives (review). Chem. Heterocycl. Compd. 29: 243-267.

Malladi S, Nadh RV, Babu SK and Babu PS, 2017. Synthesis and antibacterial activity studies of 2,4di substituted furan derivatives. Beni-Suef Univ. J. Basic Appl. Sci. 6: 345-353.

Meriga B, Mopuri R and Muralikrishna T, 2012. Insecticidal, antimicrobial and antioxidant activities of bulb exctracts of Allium sativum. Asian Pac. J. Trop. Med. 5(5): 391-395.

Nahdi MS, Martiwi INA and Arsyah DC, 2016. The ethnobotany of medicinal plant in supporting the family health in Turgo, Yogyakarta, Indonesia. Biodiversitas. 17(2): 900-906.

Naibaho FG, Bintang M and Pasaribu FH, 2015. Antimicrobial activity of Allium chinense G. Don. Curr. Biochem. 2(3): 129-138.

Najjaa H, Ammar E and Neffati M, 2009. Antimicrobial activities of protenic extracts of Allium roseum L., a wild edible species in North Africa. J. Food Agric. Environ. 7(3,4): 150-154.

Newman DJ and Cragg GM, 2012. Natural products as sources of new drugs over the 30 years from 1981 to 2010. J. Nat. Prod. 75(3): 311-335.

Putri LSE, Dasumiati, Kristiyanto, Mardiansyah, Malik C, Leuvinadrie LP and Mulyono EA, 2016. Ethnobotanical study of herbal medicine in Ranggawulung Urban Forest, Subang District, West Java, Indonesia. Biodiversitas. 17(1): 172176.

Putnik P, Gabric D, Roohinejad S, Barba FJ, Granato D, Mallikarjunan K, Lorenzo JM and Kovacevic $\mathrm{B}, 2019$. An overview of organosulfur compounds from Allium spp.: From processing and preservation to evaluation of their bioavailability, antimicrobial, and anti-inflammatory properties. Food Chem. 276: 680-691.

Rabinowitch HD and Currah L, 2002. Allium crop science: recent advances. CABI Publishing, New York, USA.

Ren G, Qiao HX, Yang J and Zhou CX, 2010. Protective effects of steroids from Allium chinense 
against $\mathrm{H}_{2} \mathrm{O}_{2}$-induced oxidative stress in rat cardiac H9C2 cells. Phytother. Res. 24: 404-409.

Safari E, Amiri M, Bahador A, Amiri M and Esmaeili D, 2014. The study of antibacterial effects of alcoholic extracts of Arum maculatum, Allium hirtifolium, and Teucrium polium against nosocomial resistance bacteria. Int. J. Curr. Microbiol. Appl. Sci. 3(2): 601-605.

Sampaio BL, Ebel RE and Costa FBD, 2016. Effect of the environment on the secondary metabolic profile of Tithonia diversifolia: a model for environmental metabolomics of plants. Sci. Rep. 6: 29265.

Satyal P, Craft JD, Dosoky NS and Setzer WN, 2017.

The chemical compositions of the volatile oils of garlic (Allium sativum) and wild garlic (Allium vineale). Foods. 6(8): 1-10.

Sharma N, 2004. Can garlic (Allium sativum) be used as a meat preservative? Trans. Kans. Acad. Sci. 107(3/4): 148-154.

Shapla UM, Solayman M, Alam N, Khalil MI and Gan SH, 2018. 5-Hydroxymethylfurfural (HMF) levels in honey and other food products: effects on bees and human health. BMC Chemistry. 12:1-18.

Sen S, De B, Easwari TS, Nagarajan AS and Maurya S, 2011. Cyclization of microbiologically active 4(furan-2-yl)-1-(pyridine-4-yl)-azetidine-2-one derivatives. Int. J. Res. Pharm. Sci. 2: 183-186.

Silalahi M and Nisyawati, 2018. The ethnobotanical study of edible and medicinal plants in the home garden of Batak Karo sub-ethnic in North Sumatra, Indonesia. Biodiversitas. 19(1): 229238.

Silalahi M, Nisyawati and Pandiangan D, 2019. Medicinal plants used by the Batak Toba tribe in the Peadundung Village, North Sumatra, Indonesia. Biodiversitas. 20(2): 510-525.
Sobolewska D, Michalska K, Podolak I and Grabowska K, 2016. Steroidal saponins from the genus Allium. Phytochem. Rev. 15: 1-35.

Wang X, Yang Y, Liu R, Zhou Z and Zhang M, 2016. Identification of antioxidants in aged garlic extract by gas chromatography-mass spectrometry and liquid chromatography-mass spectrometry. Int. J. Food Prop. 19: 474-483.

Wu X, Pang XJ, Xu LL, Zhao T, Long XY, Zhang QY, Qin HL, Yang DF and Yang XL, 2017. Two new alkylated furan derivatives with antifungal and antibacterial activities from the plant endophytic fungus Emericella sp. XL029. Nat. Prod. Res. 32: 2625-2631.

Yang F, Ding S, Liu W, Liu J, Zhang W, Zhao Q and Ma X, 2015. Antifungal activity of 40 TCMs used individually and in combination for treatment of superficial fungal infection. J. Ethnopharmacol. 163: 88-93.

Zanatta N, Alves SH, Coelho HS, Borchhardt DM, Machado P, Flores KM, Da Silva FM, Spader TB, Santurio JM, Bonacorso HG and Martins MAP, 2007. Synthesis, antimicrobial activity, and QSAR studies of furan-3-carboxamides. J. Bioorg. Med Chem. 15(5): 1947-1958.

\section{Contribution of Authors}

Naibaho FG: Conceived idea, designed research methodology, literature review and data collection Hartanto A: Conceived idea, data collection and manuscript writing

Bintang M: Literature review and data interpretation

Jamilah I \& Priyani N: Manuscript write up \& review

Putra ED: Data collection and interpretation 